\title{
SYNERGISTIC ACTION OF CHLORPYRIFOS-METHYL AND JUVENILE HORMONE ANALOGUE AGAINST LARVAL CARBOHYDRATE AND PHOSPHATASE BIOCHEMISTRY OF EPHESTIA CAUTELLA WALKER (LEPIDOPTERA: PYRALIDAE)
}

\author{
S.K. Tiwari \\ Department of Zoology \\ D.D.U. Gorakhpur University, Gorakhpur- 273 009, India \\ Corresponding author: sktzddu@rediffmail.com
}

\begin{abstract}
Sub-lethal concentrations (i.e.1,2 and 4ppm) of a synergistic mixture chlorpyrifos-methyl + methoprene in the ratio of 9:1 when exposed to third instar larvae of almond moth, Ephestia cautella Walker caused a significantly dose-dependent $(\mathrm{p}<0.05)$ reduction in glycogen level and alkaline phosphatase activity and a significantly dosedependent $(\mathrm{p}<0.05)$ enhancement in the reducing sugar lavel and the activity of acid phosphatase. The highest concentration i.e. $4 \mathrm{ppm}$ of this mixture exerted severe effect on glycogen and reducing sugars level as well as on the activities of acid and alkaline phosphatases, which along with other perturbed biochemical parameters by this synergist leads to death of the larva.
\end{abstract}

KEYWORDS: Ephestia cautella, Chlorpyrifos-methyl, Methoprene, Haemolymph, Fat body

\section{INTRODUCTION}

The control of insect pests is a puzzling problem since many decades. The almond moth, Ephestia cautella (Walker) is a serious pest of stored cereals, nuts, dried fruits, stored vegetables and cereal products in India, Florida, Northern Europe, South America, South California, Turkey, United States and other tropical and temperate regions of the world. ${ }^{12,53,45}$ Its larval stages cause serious damage to wheat, wheat-flour, maize, cocoa beans, citrus pulp, bulk grain, fig, hazelnuts, ground nuts, nuts, dried fruits, pulses, peanuts, etc. ${ }^{53,45,3}$ Considerable damage is caused by the larval feeding and by contaminating stored food with dead bodies and their own products e.g. excreta, exuviae, webbing, frass, silk and feces. ${ }^{1,26}$
Numerous Investigations have shown that synthetic organic insecticides (organochlorines, organophosphates, natural plant products and synthetic pyrethroids) affect the biochemical constituents of various tissues in insects. Most of them impose adverse effects on non-target organisms including parasites and predators, development of resistance and even contaminate the whole environment. Hence, as a safer substitute, organic insecticides like chlorpyrifos-methyl synergized with insect growth regulators (IGRs) is the need of the present day for the effective control of lepidopterous pests in general and almond moth, Ephestia cautella in particular.

Chlorpyrifos-methyl (O, O-dimethyl O3,5,6-trichloro-2-pyridyl phosphorothioate) 
is an organophosphorous insecticide effective against a wide range of insect pests in crops of commercial importance. Its limited environmental persistence and lack of cross resistance makes chlorpyrifosmethyl a more attractive prospect than DDT for indoor residual spraying. ${ }^{57}$ In addition, chlorpyrifos-methyl has been found to be much effective against $P$. interpunctella ${ }^{7}$ and Rhyzopertha dominica. ${ }^{51}$

Insect growth regulators (IGRs), also called "Third-Generation Pesticides", mimic insect's hormone and regulate the insect population through the disruption of moulting and metamorphosis. ${ }^{65,44}$ IGRs have been shown to generally have a good margin of safety for most non-target biota, as they display a very low toxicity for human and other mammals, are readily biodegradable (i.e. very low persistence in the environment), highly toxic to target insects, and leave no hazardous residues, making JHAs very useful in food preservation and storage. ${ }^{61}$

Methoprene a Juvenile Hormone Analogue (JHA) was first introduced into the market as Altosid ${ }^{\mathrm{TM}}$ (EPA Reg. No. 2724393 ) in $1975^{61}$, then later re-registered as Diacon $^{\text {TM }}$ (EPA Reg. No. 2724-788) in the 1980..$^{9,37}$ It is also registered in Australia for use in cereal grains, excluding malting barley, to control strains of the grain borer, $R$. domonica, which are resistant to synthetic pyrethroids. ${ }^{20}$ It has been useful in combinations with older neurotoxic pesticides particularly for control of pest species that have developed resistance to such pesticides. Methoprene is a long chain hydrocarbon ester considered to have higher potency and better field stability than do naturally occuring juvenile hormone. ${ }^{35}$ It is a selective, stable and potent larvicide; an ether and diunsaturated fatty acid ester; and its toxicity to insects is manifest through interference with metamorphosis, a process without parallel in mammals. It is nonpersistent and non-toxic to mammals and presents no long-term hazards to other species at recommended application rates.

Methoprene is effective on stored product insects, including T. castaneum ${ }^{4,40}$; T. confuse $^{39}, O$. surinamensis ${ }^{40,10}, R$. dominica $^{44,10}$, C. cephalonica con $^{58,59,60}$ as well as many others.

No doubt, the present study of the almond moth, E. cautella treated with synergistic mixture of chlorpyrifos-methyl and methoprene may reduce the problem of pest resistance and kill or disrupt the physiological processes of the target pest by perturbing the metabolic flux of the larva. This will explore information whether the use of less amount of chlorpyrifos- methyl in synergistic mixture is able to elicit same toxic response when used singly.

\section{MATERIALS AND METHODS}

The almond moth, Ephestia cautella(Walker) (Lepidoptera: Pyralidae) was collected from the go-downs of Central Warehouse Corporation, Nandanagar, Gorakhpur, U.P.; Food Corporation of India, Sardarnagar, Gorakhpur, U.P.; State Warehouse Corporation, Chauri Chaura, 
Gorakhpur, U.P. and State Warehouse Corporation, Sahjanwa, Gorakhpur, U.P.

A rich standard culture of this insect was maintained in the laboratory on a normal dietary medium composed of coarsely ground wheat (Triticum aestivum) mixed with 5\% (w/w) yeast powder and $10 \%$ $(\mathrm{w} / \mathrm{w})$ glucose inside large glass containers (150 $\mathrm{mm}$ diameter, $200 \mathrm{~mm}$ height) at a temperature of $26 \pm 1^{\circ} \mathrm{C}$, relative humidity $93 \pm 5 \%$ and a light regime of $12 \mathrm{hr}$ light and $12 \mathrm{hr}$ darkness.

From the above culture whenever needed, newly emerged males and females were transferred to oviposition glass chambers (35 mm diameter, $200 \mathrm{~mm}$ height). Since, E. cautella individuals do not feed during their adult stage, no food was provided to them during their confinement in these vessels. Eggs laid by the females were collected and then placed in glass chambers (consisting of $250 \mathrm{ml}$ beakers) for hatching.

A mixture of two insecticides i.e. chlorpyrifos-methyl (an organophosphate compound) and methoprene (a juvenile hormone analogue), in the ratio of 9:1 were utilized throughout the investigation. Chlorpyrifos-methyl (0,0-dimethyl 0-(3,5,6trichloro-2-pyridyl), Molecular formula: $\mathrm{C}_{7} \mathrm{H}_{7} \mathrm{Cl}_{3} \mathrm{NO}_{3} \mathrm{PS}, 98.5 \%$ (a.i.) and methoprene (isopropyl (2E, 4E)-11methoxy-3, 7, 11- trimethyl-2-1,4dodecadienoate) molecular formula: $\mathrm{C}_{19} \mathrm{H}_{34} \mathrm{O}_{3}$ (7.4\% cis and $90.4 \%$ trans) $97.8 \%$ (a.i.) used throughout the investigation were obtained from AccuStandard, Inc. 125 Market Street, New Haven, CT 06513 and have the following structural formula:<smiles>COP(=S)(OC)Oc1nc(Cl)c(Cl)cc1Cl</smiles>

\section{Chlorpyrifos-methyl}

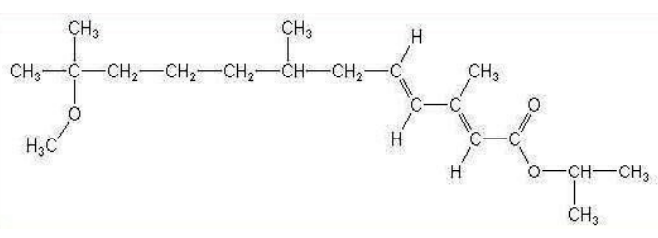

Methoprene

Toxicity experiments of chlorpyrifosmethyl, methoprene and their mixture in the ratio of 9:1 against ontogeny of Ephestia cautella, at various dose levels have been reported. ${ }^{13,14,16,18}$ For biochemical estimations, out of various concentrations of the above mentioned insecticides only such concentrations i.e. three from the mixture of chlorpyrifos-methyl + methoprene in ratio of 9:1 (1, 2 and 4 ppm) were selected, which allowed the larvae to survive and develop but caused considerable effect in the internal biochemistry of the larva that could be easily detected and assessed to prove the effectiveness of this mixture chlorpyrifos-methyl + methoprene in the ratio of $9: 1$ as chemical control measures against this lepidopterous pest.

So, freshly hatched larvae were allowed to feed on a normal dietary medium 
(kept inside $250 \mathrm{ml}$ beakers) for 13 days. On the $14^{\text {th }}$ day, 25 third instar larvae were transferred to each similar rearing chambers containing dietary medium mixed with 1,2 and $4 \mathrm{ppm}$ concentrations of the mixture of chlorpyrifos-methyl + methoprene in ratio of 9:1 and were allowed to feed for 10 days. 25 larvae were also kept as control with each set of experiment.

On the completion of 23 days, 10-15 larvae from each set, experimental as well as control were taken out. From these groups of larvae, haemolymph and fat body tissues were separately collected. ${ }^{18,14}$ The entire programme includes biochemical estimation of glycogen, reducing sugar levels and activity of acid and alkaline phosphatases in haemolymph and fat body tissues of the larva of almond moth, Ephestia cautella treated with sublethal concentrations of the mixture of chlorpyrifos-methyl + methoprene in the ratio of 9:1 as well as control.

Glycogen and reducing sugar were estimated according to the method of Van der Vies ${ }^{63}$ and Folin and $\mathrm{Wu}^{32}$ respectively. Anthrone reagent was used for glycogen estimation while for glucose estimation, alkaline copper reagent and phosphomolybdic acid reagent were used. Acid and alkaline phosphatase activity in haemolymph and fat body was determined according to the method of Andersch and Szcypinski ${ }^{6}$ as modified by Bergmeyer (1967) using p-nitrophenyl phosphate as substrate.

Results have been expressed as the mean \pm s.e. of six replicates. Significant differences between treatment groups, in order to show dose dependence, were determined by one way analysis of variance (one way ANOVA). ${ }^{50}$

\section{RESULTS AND DISCUSSION}

Sublethal concentrations (1, 2 and 4 ppm) of the mixture of chlorpyrifos-methyl + methoprene (9:1) caused a significantly dose-dependent reduction in the levels of glycogen (Table 1) and a significantly dosedependent enhancement in the levels reducing sugar (Table 2) in both the tissues of the larva.

In case of untreated larvae, the glycogen level was 2.225 and $14.720 \mathrm{mg} / \mathrm{g}$ in haemolymph and fat body respectively. The maximum decrease in glycogen level in haemolymph (20\% of the control value) and fat body ( $27 \%$ of the control value) was recorded in larvae treated with $4 \mathrm{ppm}$ concentration ofthe mixture of chlorpyrifosmethyl + methoprene (9:1). Glycogen levels, in haemolymph, were reduced to 71 (1.575 $\mathrm{mg} / \mathrm{g}), 44(0.981 \mathrm{mg} / \mathrm{g})$ and $20 \%(0.453 \mathrm{mg} /$ g) of the control value, while these levels, in fat body, were reduced to 72 (10.541 $\mathrm{mg} / \mathrm{g}), 47(6.922 \mathrm{mg} / \mathrm{g})$ and $27 \%(3.987 \mathrm{mg} /$ $\mathrm{g})$ of the control value following treatment with 1, 2 and 4 ppm concentrations of this mixture respectively (Table 1).

The level of reducing sugar, in control larvae, was 2.718 and $1.059 \mathrm{mg} / \mathrm{g}$ in haemolymph and fat body respectively. The concentration of $4 \mathrm{ppm}$ of the mixture of chlorpyrifos-methyl + methoprene $(9: 1)$ 
Table-1. Changes in the levels of glycogen in the haemolymph and fat body of the larva of $E$. cautella treated with the mixture of chlorpyrifos-methyl + methoprene (9:1)

\begin{tabular}{|c|c|c|}
\hline $\begin{array}{c}\text { Concentration of chlorpyrifos- } \\
\text { methyl + methoprene (9:1) (ppm) }\end{array}$ & \multicolumn{2}{|c|}{ Glycogen $^{\#}(\mathbf{m g} / \mathbf{g}$, wet wt.) } \\
\cline { 2 - 3 } + Haemolymph & Fat body \\
\hline Control (untreated) & $2.225 \pm 0.101(100)$ & $14.720 \pm 0.433(100)$ \\
\hline 1 & $1.575 \pm 0.067(71)$ & $10.541 \pm 0.291(72)$ \\
\hline 2 & $0.981 \pm 0.046(44)$ & $6.922 \pm 0.159(47)$ \\
\hline 4 & $0.453 \pm 0.016(20)$ & $3.987 \pm 0.084(27)$ \\
\hline
\end{tabular}

\#Values are expressed as the mean \pm s.e. of six replicates.

Values in the parentheses indicate the percentage change with control values taken as $100 \%$.

Analysis of variance showed that the response to the mixture of chlorpyrifos-methyl + methoprene (9:1) was dose-dependent $\mathrm{p}<0.05$.

caused a maximum enhancement in the amount of reducing sugar which was $217 \%$ in haemolymph and $240 \%$ in fat body with respect to their control values. The amounts of reducing sugar, in haemolymph, were increased to $140(3.812 \mathrm{mg} / \mathrm{g}), 183(4.987$ $\mathrm{mg} / \mathrm{g})$ and $217 \%(5.910 \mathrm{mg} / \mathrm{g})$ of the control value while these levels, in fat body, were enhanced to $135(1.434 \mathrm{mg} / \mathrm{g}), 173(1.831$ $\mathrm{mg} / \mathrm{g})$ and $240 \%(2.543 \mathrm{mg} / \mathrm{g})$ of the control value following treatment with 1,2 and 4 ppm concentrations of this mixture respectively (Table 2).

Table-2. Changes in the levels of reducing sugar in the haemolymph and fat body of the larva of $E$. cautella treated with the mixture of chlorpyrifos-methyl + methoprene $(9: 1)$

\begin{tabular}{|c|c|c|}
\hline \multirow{2}{*}{$\begin{array}{c}\text { Concentration of chlorpyrifos- } \\
\text { methyl + methoprene (9:1) (ppm) }\end{array}$} & \multicolumn{2}{|c|}{ Reducing sugar $($ mg/g, wet wt.) } \\
\cline { 2 - 3 } & Haemolymph & Fat body \\
\hline Control (untreated) & $2.718 \pm 0.070(100)$ & $1.059 \pm 0.086(100)$ \\
\hline 1 & $3.812 \pm 0.127(140)$ & $1.434 \pm 0.020(135)$ \\
\hline 2 & $4.987 \pm 0.209(183)$ & $1.831 \pm 0.359(173)$ \\
\hline 4 & $5.910 \pm 0.237(217)$ & $2.543 \pm 0.049(240)$ \\
\hline
\end{tabular}

\#Values are expressed as the mean \pm s.e. of six replicates.

Values in the parentheses indicate the percentage change with control values taken as $100 \%$.

Analysis of variance showed that the response to the mixture of chlorpyrifos-methyl + methoprene $(9: 1)$ was dose-dependent $\mathrm{p}<0.05$. 
Changes in acid phosphatase activities in haemolymph and fat body tissues of the larva of E. cautella treated with sublethal concentrations (1, 2 and $4 \mathrm{ppm})$ of the mixture of chlorpyrifos-methyl + methoprene (9:1) ratio have been represented in (Table 3). This mixture caused a significantly dose-dependent increase in the activity of acid phosphatase in both the tissues of the larva. In the control larvae, the acid phosphatase activity was 0.572 and $2.490 \mu$ moles substrate hydrolyzed $/ 30 \mathrm{~min} / \mathrm{mg}$ protein in haemolymph and fat body respectively. The maximum enhancement in acid phosphatase activity in haemolymph $(361 \%$ of the control value) and fat body (336\% of the control value) was observed in larvae treated with $4 \mathrm{ppm}$ concentration of the mixture of chlorpyrifos-methyl + methoprene (9:1) ratio. Acid phosphatase activity, in haemolymph, was increased to $169(0.969$ $\mu \mathrm{mol}), 261$ (1.495 $\mu \mathrm{mol})$ and $361 \%$ $(2.067 \mu \mathrm{mol})$ of the control value while the activity of this enzyme, in fat body, was enhanced to148 $(3.708 \mu \mathrm{mol}), 241(6.005 \mu$ mol) and $336 \%(8.371 \mu \mathrm{mol})$ of the control value following treatment with 1,2 and 4 ppm concentrations of this mixture respectively (Table 3 ).

Table-3. Changes in acid phosphatase activity in haemolymph and fat body of the larva of $E$. cautella treated with themixture of chlorpyrifos-methyl + methoprene (9:1)

\begin{tabular}{|c|c|c|}
\hline \multirow{2}{*}{$\begin{array}{c}\text { Concentration of chlorpyrifos- } \\
\text { methyl + methoprene (9:1) (ppm) }\end{array}$} & \multicolumn{2}{|c|}{ Acid phosphatase ${ }^{\#}$} \\
\cline { 2 - 3 } & Haemolymph & Fat body \\
\hline Control (untreated) & $0.572 \pm 0.027(100)$ & $2.490 \pm 0.038(100)$ \\
\hline 1 & $0.969 \pm 0.049(169)$ & $3.708 \pm 0.036(148)$ \\
\hline 2 & $1.495 \pm 0.047(261)$ & $6.005 \pm 0.085(241)$ \\
\hline 4 & $2.067 \pm 0.058(361)$ & $8.371 \pm 0.078(336)$ \\
\hline
\end{tabular}

\#The activities are given as $\mu$ moles of substrate hydrolyzed/ $30 \mathrm{~min} / \mathrm{mg}$ of protein and expressed as mean \pm s.e. of six replicates.

Values in the parentheses are the percentage change with control values taken as $100 \%$.

Analysis of variance showed that the response to the mixture of chlorpyrifos-methyl + methoprene $(9: 1)$ was dose-dependent $\mathrm{p}<0.05$

Sub-lethal concentrations i.e. 1, 2 and $4 \mathrm{ppm}$ of the mixture of chlorpyrifos-methyl + methoprene (9:1) caused a significantly dose-dependent reduction in the activity of alkaline phosphatase in both the tissues of the larva. In the control larvae, the alkaline phosphatase activity was 0.447 and $2.427 \mu$ moles substrate hydrolyzed $/ 30 \mathrm{~min} / \mathrm{mg}$ protein in haemolymph and fat body respectively. The maximum decrease in alkaline phosphatase activitiy, in haemolymph (29\% of the control value) and 
fat body ( $40 \%$ of the control value) was recorded in larvae treated with $4 \mathrm{ppm}$ concentration of the mixture of chlorpyrifosmethyl + methoprene (9:1) ratio. Alkaline phosphatase activity, in haemolymph, was reduced to $70(0.314 \mu \mathrm{mol}), 50(0.227 \mu \mathrm{mol})$ and $29 \%(0.131 \mu \mathrm{mol})$ of the control value while its activity, in fat body, was reduced to $84(2.039 \mu \mathrm{mol}), 66(1.593 \mu \mathrm{mol})$ and $40 \%(0.973 \mu \mathrm{mol})$ of the control value following treatment with 1,2 and $4 \mathrm{ppm}$ concentrations of this mixture respectively (Table 4).

Table-4. Changes in alkaline phosphatase activity in haemolymph and fat body of the larva of E. cautella treated with the mixture of chlorpyrifos-methyl + methoprene (9:1)

\begin{tabular}{|c|c|c|}
\hline \multirow{2}{*}{$\begin{array}{c}\text { Concentration of chlorpyrifos- } \\
\text { methyl + methoprene (9:1) (ppm) }\end{array}$} & \multicolumn{2}{|c|}{ Alkaline phosphatase $\mathbf{p}^{\#}$} \\
\cline { 2 - 3 } & Haemolymph & Fat body \\
\hline Control (untreated) & $0.447 \pm 0.012(100)$ & $2.427 \pm 0.312(100)$ \\
\hline 1 & $0.314 \pm 0.007(70)$ & $2.039 \pm 0.044(84)$ \\
\hline 2 & $0.227 \pm 0.008(50)$ & $1.593 \pm 0.028(66)$ \\
\hline 4 & $0.131 \pm 0.005(29)$ & $0.973 \pm 0.031(40)$ \\
\hline
\end{tabular}

\#The activities are given as $\mu$ moles of substrate hydrolyzed/ $30 \mathrm{~min} / \mathrm{mg}$ of protein and expressed as mean \pm s.e. of six replicates.

Values in the parentheses are the percentage change with control values taken as $100 \%$.

Analysis of variance showed that the response to the mixture of chlorpyrifos-methyl + methoprene (9:1) was dose-dependent $\mathrm{p}<0.05$.

Synergists are among the most straightforward tools for overcoming metabolic resistance because they can directly inhibit the resistance mechanism itself ${ }^{46}$. A combination of chlorpyrifosmethyl and methoprene in the ratio of $6: 1$ ppm caused significant effect in case of the flat grain beetle, C. pusillus (Schönherr), $S$. zeamais, $T$. castaneum and $P$. interpunctella ${ }^{8}$. In Australia also methoprene was combined with organophosphates that caused effective control of $S$. oryzae in wheat $^{48}$. Similarly, chlorpyrifos-methyl plus methoprene $(10+1)$ ppm was found to be effective against the major grain beetles ${ }^{21}$ i.e. S. zeamais, $S$. oryzae, $R$. dominica, $T$. castaneum and $O$. surinamensis while chlorpyrifos-methyl at $10 \mathrm{ppm}$ plus smethoprene $0.6 \mathrm{ppm}$ controlled all the strains i.e. S. oryzae, T. castaneum, $O$. surinamensis and $C$. ferrugineus except for methoprene-resistant $R$. dominica ${ }^{23}$.

In the present study, it was observed that the main advantage of chlorpyrifosmethyl plus methoprene, when mixed in the ratio of $9: 1$, is that methoprene enhances the toxicity of chlorpyrifos-methyl i.e. it behaves in a synergistic way. The probable 
cause of this synergism may be considered to be the combination of different mode of action, physical (desiccation) and chemical (toxicity) as reported $^{8}$ in case of $T$. castaneum, C. pusillus, $S$. zeamais and $P$. interpunctella following exposure of a mixture of chlorpyrifos-methyl and methoprene in the ratio of 6: 1 and $S$. zeamais, $S$. oryzae, $R$. dominica, $T$. castaneum and $O$. surinamensis following treatment $^{21}$ of a mixture of these two compounds in the ratio of $10: 1$.

Carbohydrates are one of the most essential biochemical constituents of insect tissues, many of which support optimum growth, development, reproductive activity and survival of individual species ${ }^{19,38,66,33}$. Chlorpyrifos-methyl caused a significantly dose-dependent $(p<0.05)$ decrease in glycogen level and a significantly dosedependent $(\mathrm{p}<0.05)$ enhancement in reducing sugar level in hemolymph as well as fat body tissues of the larva of this pest ${ }^{18}$. A decrease in glycogen reserve has also been reported in haemolymph and fat body tissues of Bombyx mori larva exposed to fenitrothion and ethion ${ }^{4}$, in the adults of Tribolium castaneum treated with malathion ${ }^{47}$ and in the larvae of Tribolium castaneum following exposure of malathion $^{49}$. Both lethal and sublethal concentrations of fenitrothion and ethion registered significant depletion in fat body glycogen reserves followed by concomitant increase in fat body phosphorylase and trehalase activities ${ }^{43}$. Increase in glycogen phosphorylase activity and decrease in glycogen content indicated increased glycogenolysis at tissue level. A significant decrease in glycogen reserves with a significant enhancement in reducing sugar content, in this investigation, may be ascribed to the decreased activity of glycogen synthetase and/or increased glycogenolysis, perhaps resulting from the enhanced activity of glycogen phosporylase to encounter chlorpyrifos-methyl stress. The depletion in glycogen level, in the present investigation, may also be due to direct action of chlorpyrifos-methyl on oxidative phosphorylation as observed in case of $P$. americana following treatment with lindane ${ }^{27}$. The observed enhancement in reducing sugar level, in the present investigation, may be due to gluconeogenesis and /or decreased sugar utilization as has been reported in case of C. cephalonica following exposure of malathion $^{54,55,56}$ and dimethoate ${ }^{56}$.

Methoprene caused a significantly dose-dependent $(\mathrm{p}<0.05)$ decrease in glycogen level and a significantly dosedependent $(\mathrm{p}<0.05)$ enhancement in reducing sugar level in the haemolymph as well as in the fat body of the larva of $E$. cautella $^{18}$. A significant reduction in glycogen levels was observed in insect Choristoneura fumiferana following exposure to methoprene ${ }^{42}$. Pyriproxyfen exposure also caused a significant decrease in glycogen reserve in haemolymph and fat body tissues of adult desert locust, Schistocerca gregaria ${ }^{29,52}$. Data obtained in the present investigation indicate that the 
mixture of chlorpyrifos-methyl + methoprene (9:1) ratio caused a significantly dose-dependent $(\mathrm{p}<0.05)$ decrease in glycogen level and a significantly dosedependent $(\mathrm{p}<0.05)$ enhancement in reducing sugar level in hemolymph as well as fat body tissues of the larva of E. cautella (Table 1,2). This finding is in accordance with Shakoori and Saleem ${ }^{49}$ who observed a significant decrease in glycogen reserve and a significant enhancement in reducing sugar content in the larva of $T$. castaneum following exposure of a mixture of permethrin (200 ppm) and malathion (20 ppm).

Acid phosphatase plays a significant role in catabolism, pathological necrosis, autolysis and phagocytosis ${ }^{25,11,2}$. It also helps in energy liberating processes ${ }^{24}$. Alkaline phosphatase has been reported to be involved in the transport of metabolites across the cell membranes ${ }^{64}$, secretory activity $^{36}$ and hydrolysis of phosphomonoesters under the alkaline condition $^{41}$.

Earlier studies revealed that sublethal concentrations of Chlorpyrifos-methyl and methoprene caused a significantly dosedependent $(p<0.05)$ enhancement in the activity of acid phosphatase and a significantly dose-dependent $(\mathrm{p}<0.05)$ reduction in the activity of alkaline phosphatase in the haemolymph and fat body tissues of the almond moth larvae ${ }^{18}$. Pyriproxifen induced significant enhancement in the activity of acid phosphatase in the heamolymph and fat body tissues of sun pest, Eurygaster integriceps ${ }^{67}$ but contrary to this, it caused a significant reduction in the activity of this enzyme in case of third instar larvae of the elm leaf beetle, Xanthogaleruca luteola ${ }^{62}$, both are beetles of different genera but the same compound acts in a different way. Thus, it is clear that JHAs are species specific. Similarly, JHAs induced increase in acid phosphatase activity have also been reported in various insects such as pyriproxyfen on $C$. pipiens $^{28}$, pyriproxyfen on P. gossypiella and E. insulana ${ }^{5}$ and on A. ipsilon $^{31}$. Our present results are supported by the findings of pyriproxyfen treated C. pipiens ${ }^{28}$, P. gossypiella and E. insulana $^{5}$, A. ipsilon $^{31}$ E. integriceps ${ }^{6}$.

Present data on phosphatase activity reveals that all the three sublethal concentrations of the mixture of chlorpyrifos-methyl + methoprene $(9: 1$ ratio) caused a significantly dose-dependent $(p<0.05)$ enhancement in acid phosphatase activity (Table 3 ) and contrary to this, a significantly dose-dependent $(\mathrm{p}<0.05)$ reduction in alkaline phosphatase activity (Table 4) in both the tissues of the larva of this moth. Similar results were observed in the larvae of $T$. castaneum following treatment with a mixture of permethrin and malathion $^{49}$. In addition, a significant increase in acid phosphatase activity and a significant decrease in the activity of alka-line phosphatase was also reported in the larvae of S. littoralis $^{30}$ when exposed to chlorosan- a mixture chloropyrifos $24 \%+$ cypermethrin $5 \%$. They also reported that 
when larvae of $S$. littoralis $^{30}$ were exposed to engeo- a mixture of thiamethoxam $14.1 \%$ + lambda-cyhalothrin $10.6 \%$ a significantly higher increase in acid phosphatase activity occurred in comparison to the exposure of chlorosan.

On the basis of the present investigation it may be concluded that synergistic mixture of chlorpyrifos-methyl + methoprene in the ratio of 9:1 perturbes the metabolic flux of the larva along with other biochemical parameters that affects its growth, development and contributes to lethal action of this synergist. It deserves mention that synergistic application of these insecticides of different groups having different mode of action might ofcourse meet the problem of development of insecticide resistance in almond moth, E.Cautella in particular and pest population in general.

\section{ACKNOWLEDGEMENT}

Author is thankful to Zoological Survey of India, Ministry of Environment and Forest, Prani Vigyan Bhawan, Kolkota 700053 for identification of the present insect.

\section{REFERENCES}

1. Abo-El-Saad, M.M., H.A. Elshafie, A.M. Al Ajlan and I.A. Bou-Khowh, 2011. Nonchemical alternatives to methyl bromide against Ephestia cautella (Lepidoptera: Pyralidae): microwave and ozone. Agric. Biol. J. N. Am., 2(8): 1222-1231.

2. Abou-Donia, M.B., 1978. The rple of acid phosphatase in delayed neurotoxicity induced by leptophos in hens. Biochem. Pharmacol., 27: 2055-2058.

3. Akinneye, J.O. and O.C. Ogungbite, 2013. Effect of seed extracts of five indigenous plants against the stored product moth, Ephestia cautella (Walker) (Lepidoptera: Pyralidae) Arch. Phytopathol. Plant Prot., 46(12): 14881496.

4. Amos, T.G. and P. Williams, 1977. Insect growth regulators: Some effects of methoprene and hydroprene on productivity of several stored grain insects. Aust. J. Zool., 25(2): 201-206.

5. Anan, A.R., I.M. Mona and M.H. Nagwa, 1993. Biochemical effect of pyriproxyfen juvenoid on fat and haemolymph proteins of pink bollworm, Pectinophora gossypiella (Saund.) and spiny bollworm, Earias insulana (Boisd.). Ann. Agric. Sci., 38: 761-772.

6. Andersch, M.A. and A.J. Szcypinski, 1947. Determination of alkaline phosphatase in serum with p-nitrophenylphosphate. In: Methods in Enzymatic Analysis. Bergemeyer, U.H. (ed.), Academic Press, New YOEK, pp. 571-574

7. Arthur, F.H., 1989. Pests of stored peanuts: toxicity and persistence of chlorpyrifosmethyl. J. Econ. Entomol., 82(2): 660-664.

8. Arthur, F.H., R.A. Simonaitis, J.E. Throne and J.M. Zehner, 1990. Evaluation of chlorpyrifos-methyl and chlorpyrifos-methyl plus methoprene as protectants of stored corn: small bin tests. J. Econ. Entomol., 83: 11141121.

9. Arthur, F.H., 2004. Evaluation of methoprene alone and in combination with diatomaceous earth to control Rhyzopertha dominica (Coleoptera: Bostrichidae) on stored wheat. J. Stored Prod. Res., 40: 485498.

10. Athanassiou, C.G., F.H. Arthur and J.E. Throne, 2011. Efficacy of layertreatment with methoprene for control of Rhyzopertha dominica (Coleoptera: Bostrychidae) on wheat, rice and maize. Pest Manag. Sci., 67: 380-384. 
11. Becker, N.H. and K.D. Barron, 1961. The cytochemistry anoxic and anoxic-ischemic encephalopathy in rats. Am. J. Pathol., 38(2): 161-175.

12. Boshra, S., 2007. Effect of gamma irradiation on food consumption, assimilation and digestive enzymes in Ephestia cautella (Walker) larvae. J. Stored. Prod. Res., 43(1): 49-52.

13. Chandra, A. and S.K. Tiwari, 2013. Insecticidal effect of methoprene on the pre-adult stages of almond moth, Ephestia cautella Walker (Lepidoptera: Pyralidae). J. Biol. Earth Sci., 3(2): 269-274.

14. Chandra, A. and S.K. Tiwari, 2014a. Synergistic action of chlorpyrifos-methyl and methoprene against the ontogeny of almond moth, Ephestia cautella (Walker) (Lepidoptera: Pyralidae). J. Appl. Biosci., 40(1): 57-62.

15. Chandra, A. and S.K. Tiwari, 2014b. Influence of methoprene on the larval biochemistry in haemolymph and fat body of Ephestia cautella (Walker) (Lepidoptera: Pyralidae). J. Biol. Earth Sci., 4 (2): B185-B190.

16. Chandra, A. and S.K. Tiwari, 2014c. Effects of chlorpyrifos-methyl against the third-instar larvae of almond moth, Ephestia cautella (Walker) (Lepidoptera: Pyrelidae). Acad. J. Entomol., 7 (4): 140-144.

17. Chandra, A. and S.K. Tiwari, 2014d. Influence of chlorpyrifos-methyl on the biochemistry of haemolymph and fat body of the larva of almond moth, Ephestia cautella Walker (Lepidoptera: Pyralidae). Front. Biol. Life Sci., 2(4): 85-89.

18. Chandra, A., 2015. Synergistic action of chlorpyrifos-methyl and juvenile hormone analogue on the biology and biochemisty of Ephestia cautella (Walker) larvae. Ph.D. Thesis, Deptt. of Zoology, Gorakhpur University, Gorakhpur, U.P.,India.

19. Chefurka, W., 1959. Glucose metabolism in insects. In: Biochemistry of Insects. Levenbook, L. (ed) Symposium XII of the IV Int. Congress Biochem. Pergamon Press.
20. Collins, P.J., T.M. Lambkin, B.W. Bridgeman and C. Pulvirenti, 1993. Resistence to grainprotectant insecticides in coleopterous pests of stored cereals in Queensland, Australia. $J$. Econ. Entomol., 86(2): 239-245.

21. Daglish, G.J., M. Eelkema and L.M. Harrison, 1995. Chlorpyrifos-methyl plus either methoprene or synergized phenotrin for control of Coleoptera in Queesland, Australia. J. Stored Prod. Res., 31(3): 235-241.

22. Daglish, G.J., 1998. Efficacy of six grain protectants applied alone or in combination against three species of Coleoptera. J. Stored Prod. Res., 34(4): 263-268.

23. Daglish, G.J., 2008. Impact of resistance on the efficacy of binary combinations of spinosad, chlorpyrifos-methyl and s-methoprene against five stored-grain beetles. J. Stored Prod. Res., 44: 71-76.

24. Dalela, R.C., M.C. Bhatnagar and S.R. Verma, 1978. Histochemical studies on the effect of rogor and thiodon on the activity of acid phosphatase in liver, muscles and kidney of Chana gachus. Indian J. Exp. Biol., 16: 1099-1102.

25. De Duve, C., 1959. Lysosomes, a new group of cytoplasmic particles. In: Subcellular particles. Hayasbi,T.(ed.), Ronald press, New York, pp. 128-159.

26. Dicker, N.A. and F.L. Waterhouse, 1972. Life history distributions of geographically different populations of Ephestia cautella (Walker) (Lep., Phycitidae) in gradient environments. Norsk Ent. Tidsskr., 19: 1115

27. Ela, R., W. Chefurka and J.R. Robinson, 1970. In vivo glucose metabolism in the normal and poisoned cockroach, Periplaneta americana. J. Insect Physiol., 16(11): 21372156.

28. El-Bassal, M.M., 1993. Combined effects of insect growth regulators and gamma radiation on Culex pipiens. Ph.D. Thesis, Faculty of Science, Cairo Univercity, Giza, Egypt.

29. El-Ebiarie, A.S., 2011. Effect of some insect 
growth regulators on the carbohydrates of desert locust, Schistocerca gregaria (Orthoptera: Acrididae). J. Am. Sci., 7(11): 529-537.

30. El-Mageed, A.E.M. \& S.E.M. Shalaby, 2011. Toxicity and biochemical impacts of some new insecticide mixtures on cotton leafworm Spodoptera littoralis (Boisd.). Plant Protect. Sci., 47(4): 166-175.

31. El-Sheikh, T.A., 2002. Effects of application of selected insect growth regulators and plan extracts on some physiological aspects of the black cutworm, Agrotis ipsilon (Huf). Ph.D. Thesis, Faculty of Science, Ain shams University, Cairo, Egypt.

32. Folin, O. and H. Wu, 1920. A system of blood analysis, Supplement I. A simplified and improved method for determination of sugar. J. Biol. Chem., 41(3): 367-374.

33. Friedman, S., 1970. In: Chemical Zoology. Florkin, M. and B.T. Scheer (eds.), Vol. 5(A), Academic press, New York, pp. 167-197.

34. Friedman, S., 1985. Carbohydrate metabolism. In: Comprehensive Insect Physiology Biochemistry and Pharmacology, Kerkut. G.A. and L.I. Gilbert (eds.), vol.10, Pergeman Press, Oxford, pp. 43-76.

35. Henrick, C.A., W.E. Willy and G.B. Stall, 1976. Insect juvenile hormone activity of alkyl (2E, 4E)-3, 7, 11-trimethyl-2, 4dodecadienenoates. Variations in the ester function and in the carbon chain. J. Agric. Food Chem., 24(2): 207-218.

36. Ibrahim, A.M., M.G. Higazi and E.S. Demian, 1974. Histochemical localization of alkaline phosphatase activity in the alimantry tract of the snail, Marisa cornuarietis (L.) Zool. Soc. Egypt. Bull., 26: 94-105.

37. Jenson, E.A., F.H. Arthur and J.R. Nechols, 2009. Efficacy of methoprene applied at different temperatures and rates on surface substrates to control eggs and fifth instars of Plodia interpunctella. J. Econ. Entomol., 102(5): 1992-2002.

38. Kilby, B.A., 1963. The biochemistry of the insect fat body. Adv. Insect Physiol., 1: 111-174.

39. Loschiavo, S.R., 1976. Effects of the synthetic insect growth regulators methoprene and hydroprene on survival, development or reproduction of six species of stored-products insects. J. Econ. Entomol., 69(3): 395-399.

40. Mian, L.S. and M.S. Mulla, 1982b. Residual activity of insect growth regulators against stored product beetles in grain commodities. J. Econ. Entomol., 75(4): 599-603.

41. Miao, Y., 2002. Studies on the activity of the alkaline phosphatase in the midgut of infected silkworm, Bombyx mori L., J. Appl. Entomol., 126: 38-142.

42. Mulye, H. and R. Gordon, 1993. Effects of two juvenile hormone analogs on hemolymph and fat-body metabolites of the eastern spruce budworm, Choristoneura fumiferana (Clemens) (Lepidoptera: Tortricidae). Can. J. Zool., 71(6): 1169-1174.

43. Nath, B.S., 2002. Shifts in glycogen metabolism in hemolymph and fat body of the silkworm, Bombyx mori (Lepidoptera: Bombycidae) in response to organophosphorus insecticides toxicity. Pestic. Biochem. Physiol., 74(2): 7384

44. Oberlander, H., D.L. Silhacek, E. Shaaya and I. Ishaaya, 1997. Current status and future perspectives of the use of insect growth regulators for the control of stored product insects. J. Stored Prod. Res., 33(1): 1-6

45. Oyedokun, A.V., A.A. Omoloye and F.A. Okelana, 2012. Assessment of the influence of artificial dietary supplements on aspects of biology of adult cocoa moth, Ephestia cautella. IOSR J. Pharm. Biol. Sci., 3(6): 25-30.

46. Raffa, K.F. and T.M. Priester, 1985. Synergists as research tools and control agents in agriculture. J. Agric. Entomol., 2(1): 27-45.

47. Saleem, M.A. and A.R. Shakoori, 1987a. Permethrin- and malathion-induced macromolecular abnormalities in adult Tribolium castaneum (herbst). Arch. Insect Biochem. Physiol., 5(1): 45-55. 
48. Samson, P.R., R.J. Parker and E.A. Hall, 1990. Efficacy of the insect growth regulators methoprene, fenoxycarb and diflubenzuron against Rhyzopertha dominica (F.) (Coleoptera: Bostrichidae) on maize and paddy rice. J. Stored Prod. Res., 26(4): 215221.

49. Shakoori, A.R. and M.A. Saleem, 1989. Some macromolecular abnormalities developed by the interaction of malathion and permethrin and subsequent refeeding in Tribolium castaneum larvae. Arch. Insect Biochem. Physiol., 11: 203-215.

50. Sokal, R.R. and F.J. Rohlf, 1969. Biometry: the principles and practice of statistics in biological research. San Francisco: W.H. Freeman, pp. 776.

51. Subramanyam, B., M.D. Toews, K.E. Ileleji and D.E. Maier, G.D. Thompson and T.J. Pitts, 2007. Evaluation of spinosad as a grain protectant on three Kansas farms. Crop Prot., 26: 1021-1030.

52. Tanani, M.A., K.S. Ghoneim and Kh.Sh. Hamadah, 2012. Comparative effects of certain IGRs on the carbohydrates of hemolymph and fat body of the desert locust, Schistocerca gregaria (Orthoptera: Acrididae). Florida Entomol., 95(4): 928935.

53. Temerak, S.A., 2010. Attraction of the almond moth, Cadra cautella (Walker), to ready made tea or coffee. An alternation method of methyl bromide in storehouses of date fruit in Egypt. IV Int. Date Palm Conf., Acta Hort. (ISHS), 882: 563-568.

54. Tiwari, S.K., 1987. Studies on the effect of certain insecticides on the chemistry of haemolymph and fat body of the larva of rice-moth, Corcyra cephalonica Stainton (Lepidoptera: Pyralidae). Ph.D. Thesis, Dept. of Zoology, Gorakhpur Univ. Gorakhpur, U.P. India.

55. Tiwari, S.K. and R.S. Bhatt, 1993. BHC and malathion induced changes in reducing sugar level in haemolymph and fat body of the larva of rice-moth, Corcyra cephalonica
Staint. (Lepidoptera: Pyralidae). J. Adv. Zool., 14(1): 20-24.

56. Tiwari, S.K. and R.S. Bhatt, 1996. Methoxychlor and dimethoate induced changes in biochemical components of the haemolymph and fat body of the larva of rice-moth, Corcyra cephalonica Staint. (Lepidoptera: Pyralidae). Uttar Pradesh J. Zool., 16(1): 18.

57. Tomlin, C.D.S., 2000. The Pesticide Manual, Twelfth Edition, British Crop Protection Council World Health Organisation 1997. Guidelines for predicting dietary intake of pesticide residues. Document WHO/FSF/ FOS/97.7, 2nd rev. ed., Geneva.

58. Tripathi, P., 2015. Effect of methoprene, an insect growth regulator, on the reproductive biology of rice moth, Corcyra cephalonica Staint. (Lepidoptera: Pyralidae). Ph.D. Thesis, Department of Zoology, D.D.U. Gorakhpur Uni. Goralkpur, (U.P.)

59. Tripathi, P. \& S.K. Tiwari, 2013. Effect of methoprene on the reproductive potential of rice moth, Corcyra cephalonica (Staint.) (Lepidoptera: Pyralidae). Am. Int. J. Res. Formal, Appl. Natl. Sci., 4(1): 33-37.

60. Tripathi, P. \& S.K. Tiwari, 2014. Potential of an insect growth regulator in the management of the rice moth Corcyra cephalonica Stainton, 1866 (Lepidoptera: Pyralidae). Polish J. Entomol., 83 (1): 79-97.

61. Tunaz, H. \& N. Uygun, 2004. Insect Growth Regulators for Insect Pest Control. Turk. J. Agric. For, 28(6): 377-387.

62. Valizadeh, B. \& J.J. Sendi, 2014. Sublethal effects of pyriproxyfen on some biological and biochemical properties of elm leaf beetle, Xanthogaleruca luteola (Col.: Chrysomelidae). J. Entomol. Soc. Iran, 33(4): 59-70

63. Van der Vies, J., 1954. Two methods for the determination of glycogen in liver. Biochem. J., 57(3): 410-416.

64. Vorbrodt, A., 1959. The role of phophatase in interacellular metabolism. Postepy, Hig Med. 
Dosw., 13: 200-206.

65. Williams, C.M., 1956. The juvenile hormone of insects. Nature, 178: 212-213.

66. Wyatt, G.R., 1967. The biochemistry of sugars and polysaccharides in insects. Adv. Insect Physiol., 4: 287-360.
67. Zibaee, A., I. Zibaee and J.J. Sendi, 2011. A juvenile hormone analog, pyriproxyfen, affects some biochemical components in the hemolymph and fat bodies of Eurygaster integriceps Puton (Hemiptera: Scutelleridae). Pestic. Biochem. Physiol., 100(3): 289-298. 